\title{
Parameters affecting biomass drying during combustion in moving grate furnaces
}

\author{
Lina Vorotinskienè \\ Laboratory of Combustion Processes, \\ Lithuanian Energy Institute, \\ Breslaujos St. 3, 44403, \\ Kaunas, Lithuania \\ Email:Lina.Vorotinskiene@lei.lt
}

\begin{abstract}
The most efficient way so far to extract energy from renewable sources is combustion of solid fuel. Solid fuel furnaces of moderate capacity (5-10 MW) equipped with reciprocating grates are most popular. Grate combustion is a well-developed technology; however, to burn biofuel in this type of furnaces in the optimal and safe way, the fuel must be of high quality and have at least constant moisture content. However, increasing demand for biofuel results in increasing prices. To remain in the market and to stay competitive, heat producers choose to utilise moist biofuel of lower quality, whose moisture content can vary and reach up to $60 \% \mathrm{wt}$. The burning on the grate of such biofuel is complicated as the drying process occupies most of the space in the furnace.

The purpose of this work was to analyse processes taking place in a furnace, such as: primary air supply, influence of flue gas recirculation and radiation from hot surfaces of the furnace to biofuel drying. Analysis of the data obtained would provide technical decisions facilitating optimal fuel combustion in a furnace without additional investments. Analysis of biofuel drying was performed in an experimental setup with a fixed fuel bed. The experiments were performed with wood chips and four different drying fluid temperatures.

The results of experimental studies have shown that the drying rate of biofuels upper layers is strongly influenced by radiation from hot surfaces and the moisture content of the sample decreases by $18 \%$ wt.
\end{abstract}

Keywords: biofuel, primary air, furnace, radiation

\section{INTRODUCTION}

The widespread and long-term use of fossil fuel resulted in global climate changes leading to more frequent heat waves, storms and floods [1]]. Due to these reasons more stringent environmental regulations were introduced to decrease the emissions of $\mathrm{CO}_{2}$ and to substitute fossil fuel with renewable energy sources. Biomass is the most prospective alternative to fossil fuel in thermal energy production. Also, it is used for district heating, mostly in North Europe. As an example, in Lithuania two thirds of fossil fuel used to produce heat for district heating have been replaced by biomass [2]. It was achieved by building small and medium scale heating 
plants (5-10 MW). These systems are equipped with reciprocating grates furnaces, water boilers and condensing economisers, which ensure low emissions of environmental pollutants (CO, NOx, etc.) burning biomass with moisture content in the range of $30-55 \%$ [3]. However, the continued development of renewable energy source usage for heat production leads to increased demand for biomass (wood chips), resulting in price increase of good quality biofuel. Due to this reason, to remain in the market and to stay competitive, heat producers choose to use moist biofuel of lower quality, such as stem wood, coniferous bark, with varying moisture content that can reach up to $60 \%$ wt. Besides, the lower heating value of such fuel is only $6 \mathrm{MJ} /$ $\mathrm{kg}$, while the lower heating value of biofuel with moisture content of $30 \% \mathrm{wt}$. is about $12 \mathrm{MJ} / \mathrm{kg}$ [我. In this case, combustion on the grate of so moist fuel becomes complicated as the drying process occupies most of the space in the furnace and combustion heat from the lower layer is consumed for drying up the upper fuel layer [5]. Moreover, it could cause burning instability and incomplete combustion, which leads to increased $\mathrm{CO}_{2}$ emissions.

One of the solutions to avoid these problems is an additional fuel drying before supplying to the furnace. For this purpose, superheated steam dryers, rotary dryers, bed dryers and fluidized bed dryers [6-8] are used. Using these systems, biomass could be dried out to the required moisture content resulting in improved energy quality, energy efficiency and reduced negative environmental impacts during combustion. However, these advantages come with certain drawbacks. The drying system must be selected precisely evaluating the energy efficiency, risk of fire and drying emissions to reach the desired moisture content of supplied biofuel. Pang and Mujumdar [9] reviewed a packed moving bed, rotary and pneumatic drying systems. According to the authors, these systems are suitable for drying of wood chips. The packed moving bed dryer is working with lower drying temperature $\left(80-150^{\circ} \mathrm{C}\right)$ and occupies a larger land area in the heating plant, while the rotary dryer operates at a drying temperature from $200^{\circ} \mathrm{C}$ to $500^{\circ} \mathrm{C}$ resulting in high drying capacity, but it is with a higher risk of fire. Myllyma et al.
[10] performed drying experiments in a fixed bed batch-dryer to investigate drying possibility using excess heat and solar energy in a municipal CHP plant. The results revealed that the temperature of the drying agent should be over $70^{\circ} \mathrm{C}$ as the drying time decreases in half when the drying agent temperature increases from $50^{\circ} \mathrm{C}$ to $70^{\circ} \mathrm{C}$, while negligible changes of the drying time occur when the agent temperature increases from $70^{\circ} \mathrm{C}$ to $90^{\circ} \mathrm{C}$. Similar drying experiments using different drying air temperatures $\left(120^{\circ} \mathrm{C}, 140^{\circ} \mathrm{C}, 160^{\circ} \mathrm{C}\right.$ and $\left.180^{\circ} \mathrm{C}\right)$ were performed by Danielsson and Rasmuson [11]. The authors also investigated the release of volatile organic components during the drying process. The results showed that part of the calorific value is lost when drying biofuel with air at a temperature exceeding $100^{\circ} \mathrm{C}$ because of evaporation of monoterpenes. Release of these monoterpenes is most intense in the beginning of the drying process during the period of up to 30 minutes, and the amount depends on the nature of biomass and the temperature of the drying agent. The higher the temperature of the drying agent, the more intense the evaporation of volatile organic compounds (VOC) and therefore the loss of calorific value. It has been also determined that heating biofuel with superheated steam leads to a higher VOC release rate compared to the case when using air as the drying medium.

In summary, additional drying systems require additional costs for installation in the heating plants and equipment, occupy large spaces and lead to release of VOC during biomass drying with the medium with temperature of over $100^{\circ} \mathrm{C}$, resulting in a lowered heating value. In order to avoid the loss of VOC and additional expenses for biofuel drying when firing wet biofuel, optimizations of furnaces are necessary, such as corrections of the grate motion regimes using the moisture prediction method [12, 13] or intensification of fuel drying on the grates. For this purpose, biomass drying experiments were performed to determine the influence of the primary air supply and flue gas recirculation products injected through the bottom of the grate and exposure of the biofuel bed to radiation from incandescent surfaces of the furnace to biofuel drying in the furnace. 


\section{MATERIALS AND METHODS}

\section{Equipment}

Biofuel drying was analysed in an experimental setup (reactor) equipped with a fixed fuel bed. The scheme of the setup is shown in Fig. 1. The experimental equipment consists of four main components: electrical heater, steam generator, drying chamber and two infrared lamps. Air needed for the experiment is supplied from a compressor through two heating coils to preheat air to the desired temperatures of $50{ }^{\circ} \mathrm{C}$, $100{ }^{\circ} \mathrm{C}, 150{ }^{\circ} \mathrm{C}, 200{ }^{\circ} \mathrm{C}$. The temperature of hot air was measured and controlled by means of a K-type thermocouple installed in front of the reactor. The readings of the thermocouples were collected and processed by a PICO TC-08 application. To simulate the effect of hot recirculation flue gases, steam was introduced into preheated air stream. The absolute humidity of air was increased from 5 to $17 \mathrm{~g} / \mathrm{m}^{3}$. The drying air flow rate was maintained constant at $18 \pm 1 \mathrm{~m}^{3} / \mathrm{h}$. The fuel bed height was $0.23 \mathrm{~m}$, with thermocouples embedded at various heights to determine the drying zone progression through the bed (Fig. 1). Air humidity was measured by a measurement unit Testo 454 with a connected relative humidity (RH) sensor. To simulate the furnace radiation, two infrared lamps were installed above the biofuel bed with power output of $2 \mathrm{~kW}$ each. This corresponds to the furnace radiation of $50 \mathrm{~kW} / \mathrm{m}^{2}$.

\section{Procedure}

It is known that biofuel does not stay longer than ten minutes in the drying zone on a grate in a furnace of the heating plant. If biofuel with high moisture content (approx. 60\% wt.) is supplied into the furnace, it does not dry out completely in 10 minutes; therefore, in the largest part of the furnace fuel is drying out rather than burning. The part of a $6 \mathrm{MW}$ furnace that was simulated corresponds to the drying zone. In this furnace, the grate movement velocity is $0.003 \mathrm{~m} / \mathrm{s}$. Therefore, the time fuel spends until it burns out in the furnace is approximately 30 minutes. The drying zone occupies $1 / 3$ of the furnace length; therefore, the actual time spent in this zone is approximately 10 minutes. By adjusting the grate movement velocity in the drying zone, the biofuel residence time in this zone can be extended. To clarify the influence of residence time to biofuel drying, biofuel was left to dry out for 30 minutes during experiments.

Before performing experiments in the biofuel drying chamber, biofuel was specifically prepared. To imitate the situation when moist biofuel (approx. 60\% wt. moisture content) can

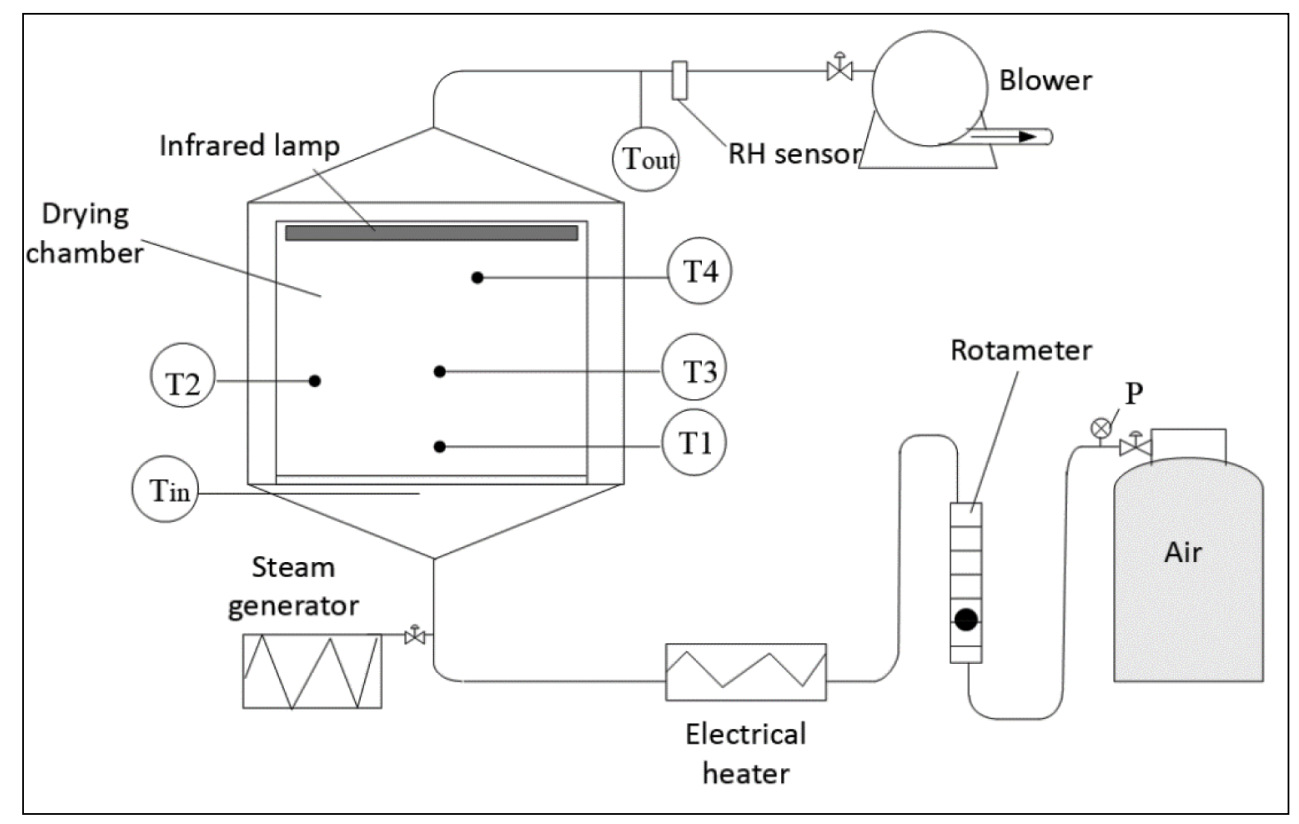

Fig. 1. Scheme of experimental rig for biomass drying 
enter the furnace in certain seasons, it was additionally soaked in water to saturate it sufficiently with humidity in the lab. Wood chips were loaded into a steel crate and submerged to a vessel filled with water together with the crate and left to soak in the vessel for 16 hours. After the crate containing biofuel is lifted out, the sample is left to drain for 2 hours in the temperature of a closed room.

To imitate the feeding of wet cold biofuel to a hot furnace, the entire rig was preheated during experiments. The temperature of drying air was selected to replicate the temperatures of primary air supplied to the medium power capacity (6 MW) furnace. After the parameters of the unloaded experimental setup (the specified air flow rate and temperatures) reached the steady state, the drying chamber was loaded with a layer of wood chips for an experiment. The data from thermocouples were collected and processed by the PICO TC-08 software. The fraction of residual moisture content in biofuel is estimated by measuring the humidity of outflow air and recalculating it into the moisture content of exhaust flow by calculations presented in previous work [12]. The moisture content of flow was recalculated to the residual moisture content of solid fuel $Y_{m}$ by (1).

$$
Y_{m}=1-\left(\frac{Y_{0}-Y_{(t)}}{Y_{0}}\right),
$$

where $Y_{0}$ is the normalized initial weight of the sample, $Y_{(t)}$ is the normalized weight of the sample at the time moment $t$. The normalized weight of the sample is calculated based on minimum and maximum values by (2) [14]. It allows to compare obtained results as the initial sample mass was different in all experiments while maintaining the same height of the bed.

$$
Y_{0}=\frac{m_{\max }-m_{\min }}{m_{\min }},
$$

where $m_{\max }$ is the initial mass of the sample $\mathrm{g}$, $m_{\text {min }}$ is dry sample mass $g$, it is accepted that $m_{\max }>m_{\min }$. These calculations are suitable only for wet biofuel and do not fit for dry fuel as a combustion process starts earlier. Thunman and Leckner [15] stated that the combustion of biofuel on grates could start when the moisture content of biofuel is less than $45 \%$.

\section{Biomass characteristics}

A biomass mix of bark chips with chips of different tree branches was used for the experiment. The main characteristics of the used samples are presented in Table 1. Before feeding the sample into the experimental drying chamber and after the experiment is complete, samples were taken, and their moisture content was determined according to the LST EN ISO 18134-1:2015 standard. The proximate analysis of this wood chips sample was performed using an IKA C5000 calorimeter and a Flash 2000 CHNS analyser in accordance with: LST EN 14918 (HHV), LST EN 14775 (ash content), LST EN 15148 (volatile content) and LST EN 15104 (CHNS content).

Table 1. The characteristics and compositions of used sample

\begin{tabular}{c|c|c}
\hline Parameter & $\begin{array}{c}\text { Chips of vario- } \\
\text { us species of } \\
\text { tree branches } \\
\text { with bark }\end{array}$ & $\begin{array}{c}\text { Standard } \\
\text { deviation }\end{array}$ \\
\hline Ultimate analysis wt.\% & \\
\hline Carbon & 48.6 & 1.17 \\
\hline Hydrogen & 5.80 & 0.49 \\
\hline Oxygen (diff.) & 41.49 & 0.15 \\
\hline Nitrogen & 0.60 & 0.04 \\
\hline Sulphur & $<0.01$ & - \\
\hline Proximate analysis wt.\% & \\
\hline Moisture & 36 & 0.10 \\
\hline Ash & 3.50 & 0.05 \\
\hline $\begin{array}{c}\text { Higher heating value } \\
\text { (HHV), kJ/kg }\end{array}$ & 18998 & 52.30 \\
\hline
\end{tabular}

The granulometric composition of biofuel was determined by using sieves (Fig. 2). The biofuel particle size parameter is important because many particle systems can be homogenized for a simpler heat and mass transfer considerations. The major part (more than 60\%) of biofuel samples used in the experiments consisted of particles larger than $10 \mathrm{~mm}$ in length.

\section{RESULTS AND DISCUSSION}

To investigate the parameters having the largest effect on biofuel drying on the grate furnace, three types of tests were performed. The biofuel was impacted by: a) hot air, which simulated the furnace primary air inlet, b) hot air and 


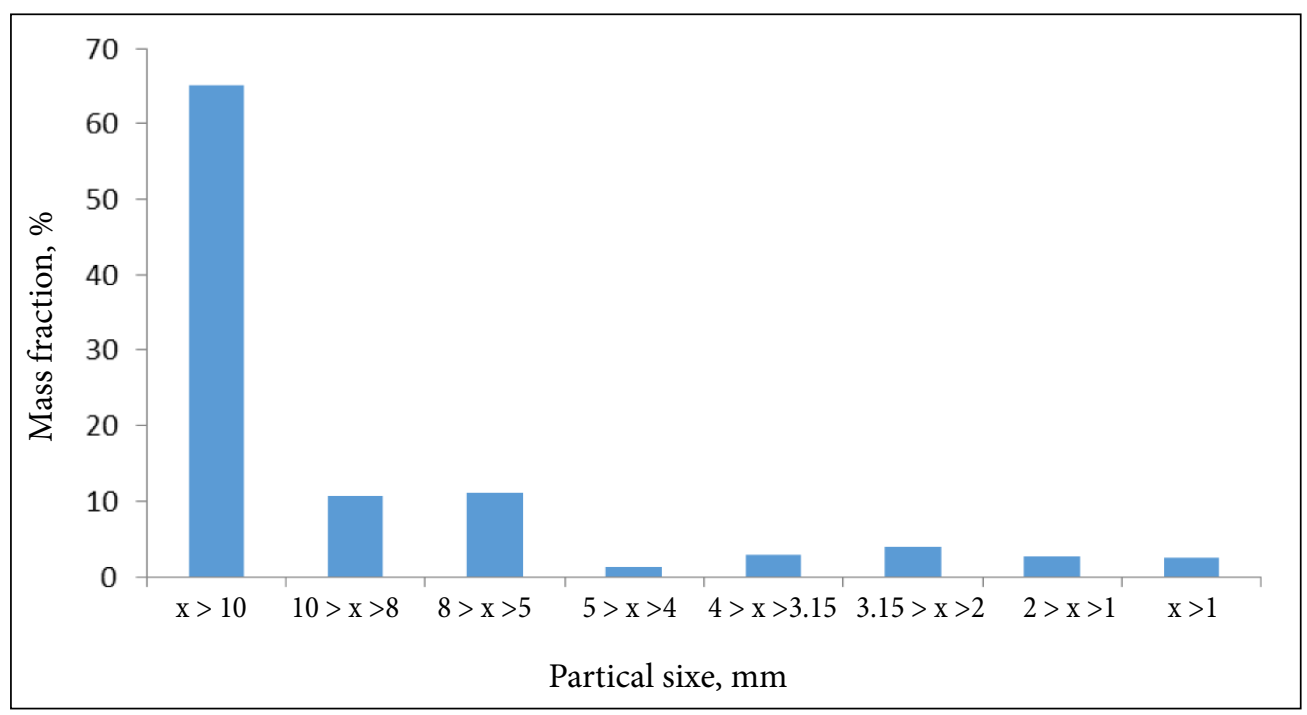

Fig. 2. Distribution of particles of different lengths as cumulative percentages of mass

the steam, which simulated the recirculation of the flue gases from the furnace, and c) infrared lamps imitating radiation of the furnace.

\section{Effect of air temperature}

Preheated air enters the stationary fuel bed from bottom to top. Having flown through the biofuel bed, the drying agent enters the flue gas exhaust vent, where its humidity was measured by a $\mathrm{RH}$ sensor to estimate the average residual moisture content in biofuel. During all the experiments, the temperature changes in 4 different locations of the drying chamber were recorded. The temperature sensors were located and numbered as shown in Fig. 1.

Figure 3 shows the temperature changes in the stationary biofuel bed. The experimental results show that higher inlet air temperature leads to heating through the entire biofuel bed that is being dried. The temperature sensors installed in various locations of the drying chamber revealed that the biofuel bed heats up non-uniformly independent of the supplied air temperature. When drying wood chips by air of $50^{\circ} \mathrm{C}$ temperature, the temperature in the layers of the biofuel bed did not change and remained approximately $20^{\circ} \mathrm{C}$ during the entire experiment. At so low drying temperature, drying takes place in the lower layer of the bed, but it is very slow, because no change in the temperature of the lower layer was identified for 30 minutes. When drying biofuel by air of $50^{\circ} \mathrm{C}$ temperature, the temperature of the biofuel bed only reaches $20^{\circ} \mathrm{C}$; therefore, the condensation process characteristic of drying wet biofuel in the stationary bed takes place with low intensity and in a narrow part of the bed. The condensation process intensifies with raising temperature of the drying air. When drying biofuel by air of $100^{\circ} \mathrm{C}$ temperature, the temperature changes show that the condensation process manifests itself in the lower and near-wall bed layers first, already after 6 minutes from the start of the experiment, as shown by the temperature stabilisation. The condensation process reaches the middle of the bed after 15 minutes, when the sensor T3 registers the temperature of $20^{\circ} \mathrm{C}$. At 23 minutes from the start of the experiment, the condensation process reaches also the upper layer of the bed, and heating through the entire biofuel bed is observed. When drying biofuel with air of $50^{\circ} \mathrm{C}$ and $100^{\circ} \mathrm{C}$ temperatures, it takes longer to observe drying of the lower layer compared to the case when the drying air temperature is $50^{\circ} \mathrm{C}$ or $200^{\circ} \mathrm{C}$. The temperature registered by the sensor $\mathrm{T} 1$ changes most rapidly, which shows that the layer closest to the grate dries out most intensely. When drying biofuel by air of $150^{\circ} \mathrm{C}$ temperature, the condensation process in the lower layer of the bed is very insignificant, and it disappears entirely when the drying air temperature is $200^{\circ} \mathrm{C}$, which is shown by the increasing temperature at the sensor T3 from the very start of the experiment. 

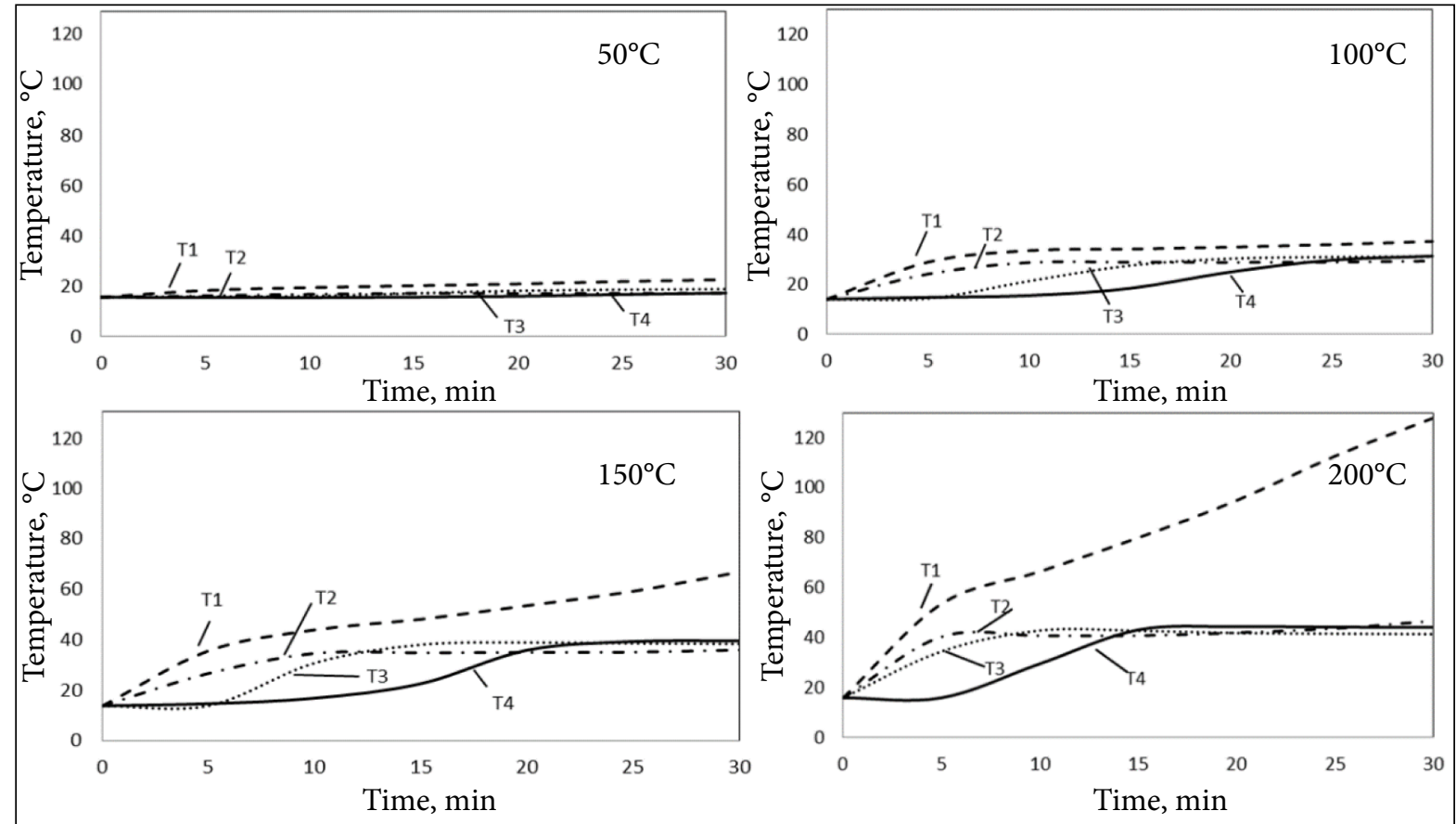

Fig. 3. Temperature changes depending on the supplied air temperature

Figure 4 presents the residual moisture content in biofuel at a certain time moment and the moisture loss rate. Wood chips were dried out at four values of the drying air temperature. The experimental results have shown that the moisture loss in the sample intensifies with increasing inlet

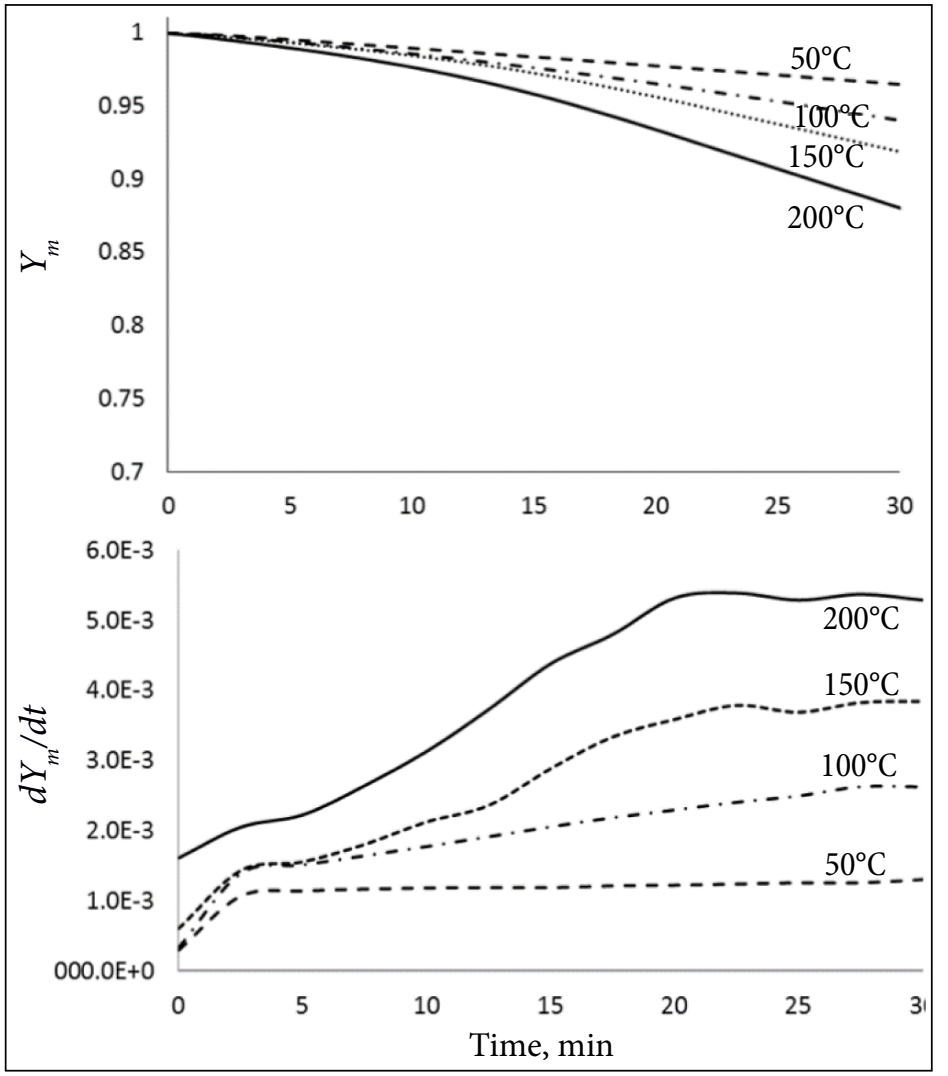

Fig. 4. Residual normalized moisture content $\left(Y_{m}\right)$ and moisture lost rate $\left(d Y_{m} / d t\right)$ : biomass drying with different air temperatures 
air temperature. When drying wood chips, the moisture loss rate is intense during the first minutes of the experiments regardless of the air supply temperature. After approximately $3 \mathrm{~min}$ utes from the start of the experiment, stabilization of the moisture loss rate is observed. Stabilization of temperature and moisture loss rate is achieved because energy is used for evaporation of condensed moisture rather than for heating of wood chips. When drying wood chips by air of $50^{\circ} \mathrm{C}$ temperature, the moisture loss rate remains constant for the remaining time of the experiment. When the temperature of the inlet air is $100^{\circ} \mathrm{C}$ or higher, moisture loss intensifies starting at 5 minutes from the start of the experiment and stabilizes again only at the end of the experiment at approximately 25 minutes. When drying with air of $100^{\circ} \mathrm{C}$ and $150^{\circ} \mathrm{C}$, moisture loss rate is similar during the first minutes, but after 6 minutes when drying with air of $150^{\circ} \mathrm{C}$ temperature, moisture loss intensifies due to intense drying of the lower layer and heating of the middle layer (Fig. 3). The moisture loss rate stabilizes when the temperature in the bed layers stabilizes. When drying with air of $150^{\circ} \mathrm{C}$ temperature, the moisture loss rate stabilizes at the end of the experiment at approximately 23 minutes. Wood chips dried out most intensely at the drying air temperature of $200^{\circ} \mathrm{C}$. In this case, intense decrease of the sample humidity is observed right from the start of the experiment, because air with temperature of $200^{\circ} \mathrm{C}$ contains much energy that heats up the lower layer of the sample quickly and condensation does not take place there. The condensation process is pushed to the higher layer where air has lost part of its energy and cools down to the dew point temperature. After 20 minutes from the start of the experiment, when fuel is exposed to air with the temperature of $200^{\circ} \mathrm{C}$, drying out becomes stable and the residual moisture content in the sample is 0.88 after 30 minutes, whereas it is only 0.98 when drying out by air with the temperature of $50^{\circ} \mathrm{C}$.

\section{Effect of flue gas recirculation additions}

Flue gas recirculation is installed in the currently operating biofuel boilers. Recirculation means returning flue gas back into the combustion chamber. The biofuel boilers are designed in a way where the recirculation products are supplied into the combustion chamber through the bottom of the grate. To intensify biofuel drying in the drying zone of the grate, it is necessary to research not only the influence of primary air to biofuel drying, but the influence of recirculation products as well. Biofuel drying experiments were performed imitating the influence of recirculation products. The obtained experimental results have shown that the drying intensity of biofuel layer depends significantly on the temperature of recirculation products.

Similar to the case of drying biofuel by dry heated air, temperature changes in layers of the biofuel bed were recorded in experiments involving drying the sample by an air-steam mixture. The obtained data are shown in Fig. 5 . When drying biofuel by the air-steam mixture having the temperature of $50^{\circ} \mathrm{C}$, the temperature in the bed reached $30^{\circ} \mathrm{C}$, which demonstrates that the air-steam mixture transfers heat better than dry air, because in case of drying with air only at $50^{\circ} \mathrm{C}$, the bed temperature was lower by $10^{\circ} \mathrm{C}$. When supplying the air-steam mixture with temperature of $50^{\circ} \mathrm{C}$ from the bottom of the grate, the temperature of the lower and nearwall layers of the bed stabilised after 10 minutes and the processes of condensation and drying started. Five minutes after that, the condensation process took place also in the middle of the bed. Heating throughout the entire bed was observed only at the end of the experiment; therefore, at these experimental conditions with low temperature of the drying medium, drying has low intensity. When drying the sample using the air-steam mixture with the temperature of $100^{\circ} \mathrm{C}$, condensation manifests itself already after 5 minutes in the lower and near-wall layers of the bed and reaches the middle of the bed after 13 minutes. Drying of the upper layer is observed after 15 minutes from the start, when the temperature at T4 starts to increase. Heating throughout the entire bed to the temperature of $40^{\circ} \mathrm{C}$ is observed after 25 minutes from the start of the experiment, which is faster by 5 minutes compared to drying the sample with the airsteam mixture with the temperature of $50^{\circ} \mathrm{C}$. In case of the temperature of $150^{\circ} \mathrm{C}$ of the supplied mixture, the lower and near-wall layers, as well as the middle of the bed reach the temperature of 


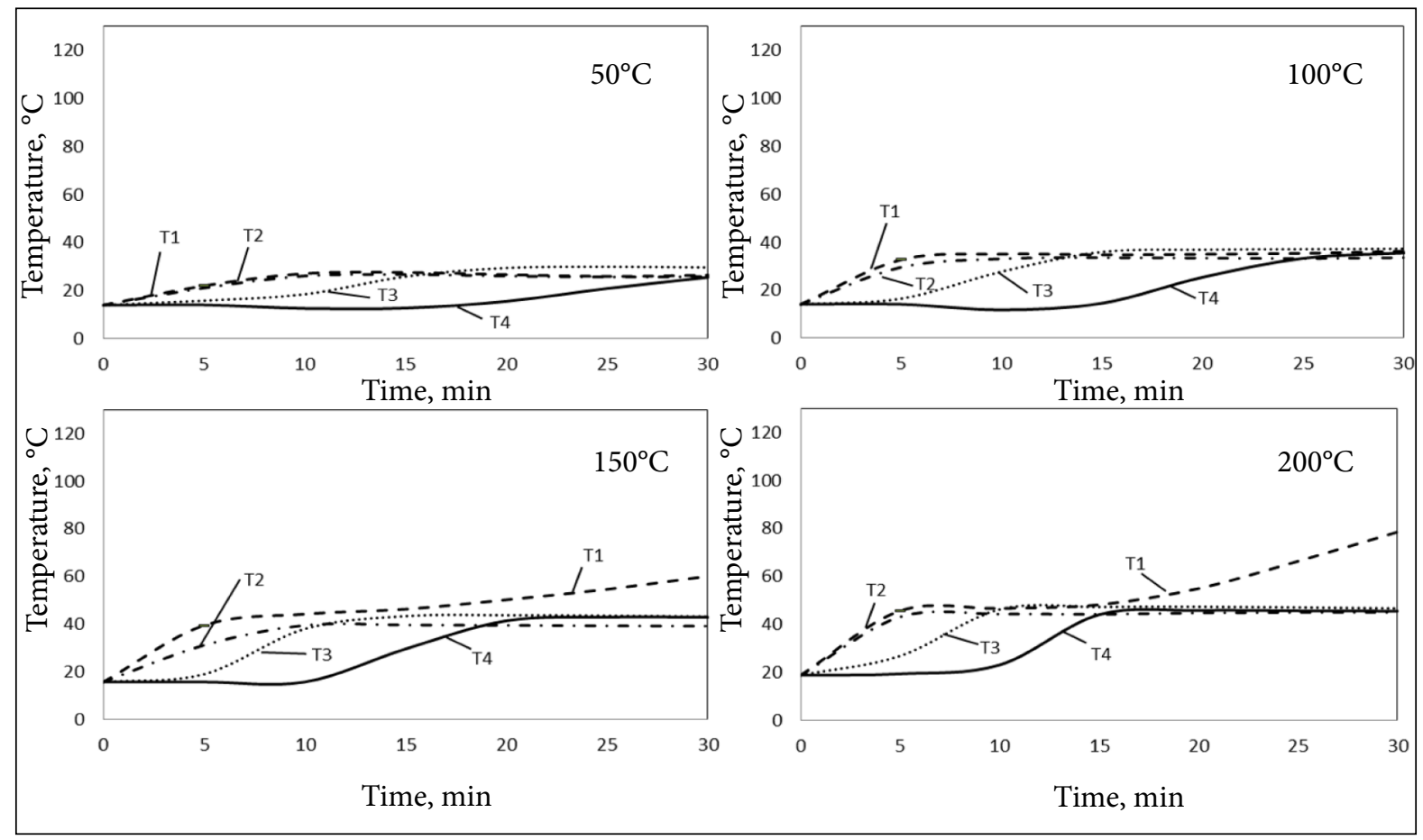

Fig. 5. Heating through of a biofuel bed being dried out with different air-steam mixture temperatures

$40^{\circ} \mathrm{C}$ at approximately 10 minutes. During the period of 10-15 minutes from the start of the experiment, an intense water evaporation process takes place in the lower layer of the bed, as shown by stabilization of the T1 temperature, after which the lower layer starts to dry out, as shown by increasing temperature of the $\mathrm{T} 1$ sensor. The entire bed heats up all over to the temperature of $40^{\circ} \mathrm{C}$, which does not exceed the temperature reached by drying biofuel with the air-steam mixture of $100^{\circ} \mathrm{C}$ temperature, but it reaches the same temperature 5 minutes earlier than in case of drying biofuel with the air-steam mixture of $100^{\circ} \mathrm{C}$ temperature. When drying biofuel with the air-steam mixture of $200^{\circ} \mathrm{C}$ temperature, condensation starts in the largest part of the bed at approximately 10 minutes. Analogous to the case of supplying the air-steam mixture of temperature of $150^{\circ} \mathrm{C}$ to the drying chamber, in case of the mixture temperature of $200^{\circ} \mathrm{C}$, an intense drying process takes place in the lower part of the bed in the period from 10 to 15 minutes and after 15 minutes from the start of the experiment, heating throughout the entire bed, and drying of the lower layer of the bed is observed.

The changes in temperature when drying biofuel by the air-steam mixture imply that conden- sation on the colder surfaces of the sample located higher takes place inevitably in all the bed layers when drying wood chips. The condensation process in a layer is indicated by the temperature stabilisation.

Figure 6 shows the fraction of moisture at certain time moments when drying by the airsteam mixture. In these drying conditions, emission of moisture is reduced because of the condensation process that takes place here inevitably due to cold biofuel supplied to the furnace.

The drying agent cools down as it flows around moist and cold biofuel, is saturated with humidity and condenses on warmer surfaces located higher in the layer. The more saturated the drying agent with humidity, the more intense this process. Independently of the temperature $\left(50-200^{\circ} \mathrm{C}\right)$ of the air-steam mixture supplied through the bottom of the bed to the biofuel drying zone, a "dead zone" appears. The "dead zone" is a zone appearing at the beginning of the biofuel furnace of the grate, where not even fuel drying takes place [5]. When drying biofuel with the air-steam mixture of $50^{\circ} \mathrm{C}$, biofuel drying stagnation lasted for even 12 minutes, and in case of the drying mixture temperature of $100^{\circ} \mathrm{C}$, it lasted approximately 5 minutes (Fig. 6 ); therefore, the residual moisture in the sample 


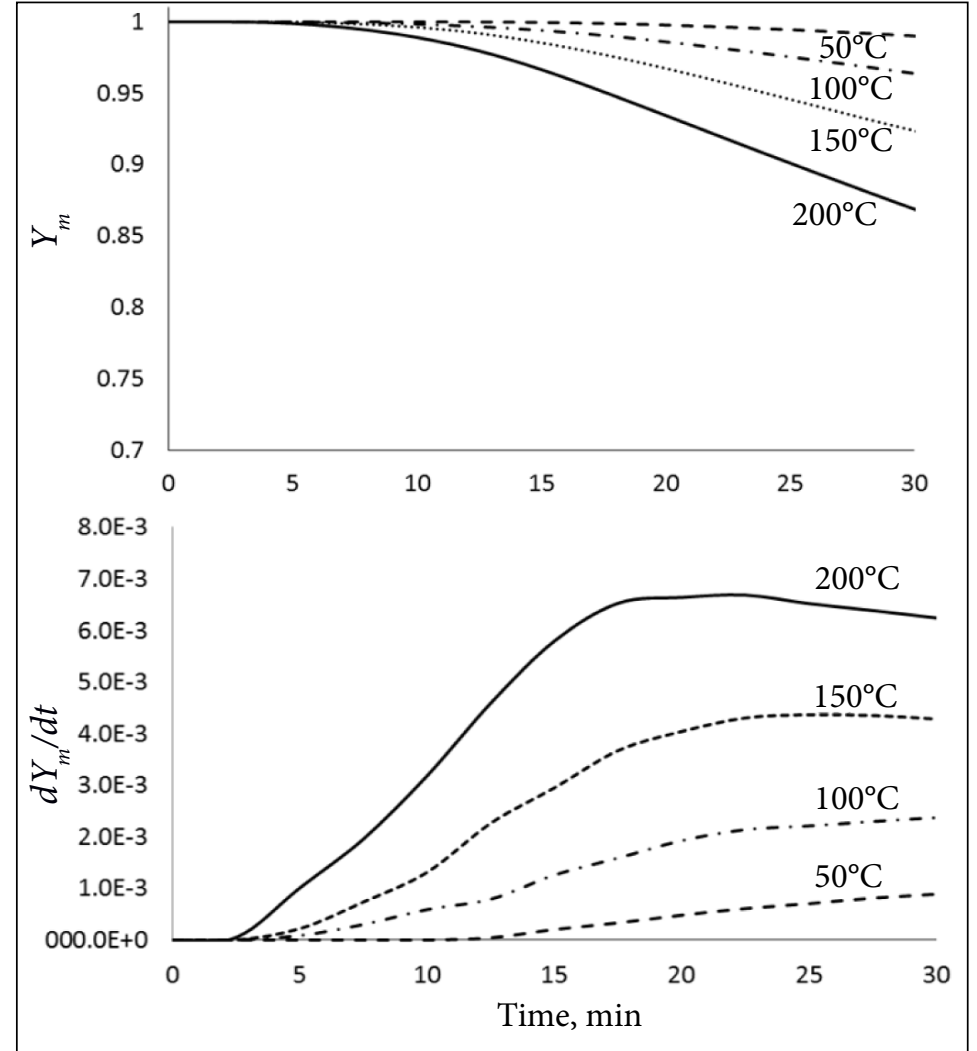

Fig. 6. Residual normalized moisture content $\left(Y_{m}\right)$ and moisture lost rate $\left(d Y_{m} / d t\right)$ : biomass drying with different air-steam mixture temperature changed slowly during the entire experiment and was reduced from 0.99 to only 0.975 . For repeated water conversion by steam, heat energy or additional time is necessary. The drying agent of low temperature $\left(50-100^{\circ} \mathrm{C}\right)$ contains too little heat energy required to evaporate condensed moisture; therefore, the humidity loss rate is only approximately $1.5 \times 10^{-3}$.

When drying chips of branches of various wood types by overheated water steam of $150-200^{\circ} \mathrm{C}$, we observe the appearance of the same undesirable "dead zone" in the beginning of the drying experiments. When supplying the overheated air-steam mixture from the bottom of the grate, the lifetime of the stagnation zone is approximately three minutes, followed by intense fuel drying. The drying rates of the samples stabilised after 20 minutes at the steam temperature of $150^{\circ} \mathrm{C}$ and after 15 minutes for the steam temperature of $200^{\circ} \mathrm{C}$. After the entire bed heats up entirely, moisture loss becomes stable and drying rate starts to reduce only after the lower bed layer dries out. When drying the sample of wood chips for 30 minutes with the air-steam mixture of $50^{\circ} \mathrm{C}$, the drying process is very slow and the residual moisture con- tent in the sample is 0.99 . When the temperature of the drying agent is raised to $200^{\circ} \mathrm{C}$, the residual moisture content in the sample after $30 \mathrm{~min}$ utes of drying is 0.86 .

\section{Effect of primary air temperature and radiation}

The earlier experiments clarified the influence of the primary air supply and flue gas recirculation products on the biofuel drying process. Since the purpose of the analysis is to clarify the influence of all the factors on biofuel drying on a grate, analysis was performed imitating radiation from the incandescent surfaces of the furnace. Heat produced during combustion heats up the internal surfaces of the furnace that radiate heat to the biofuel surface and influence the drying intensity as well.

Figure 7 shows the changes of the wood chips temperature in various points of the fuel bed. When drying biofuel with $50^{\circ} \mathrm{C}$ temperature dry air and in the presence of infrared radiation of $50 \mathrm{~kW} / \mathrm{m}^{2}$ to the upper layer of the fuel bed, the temperature of the entire bed amounts to only $25^{\circ} \mathrm{C}$ after 15 minutes. During the entire experimental period, the temperature did not 


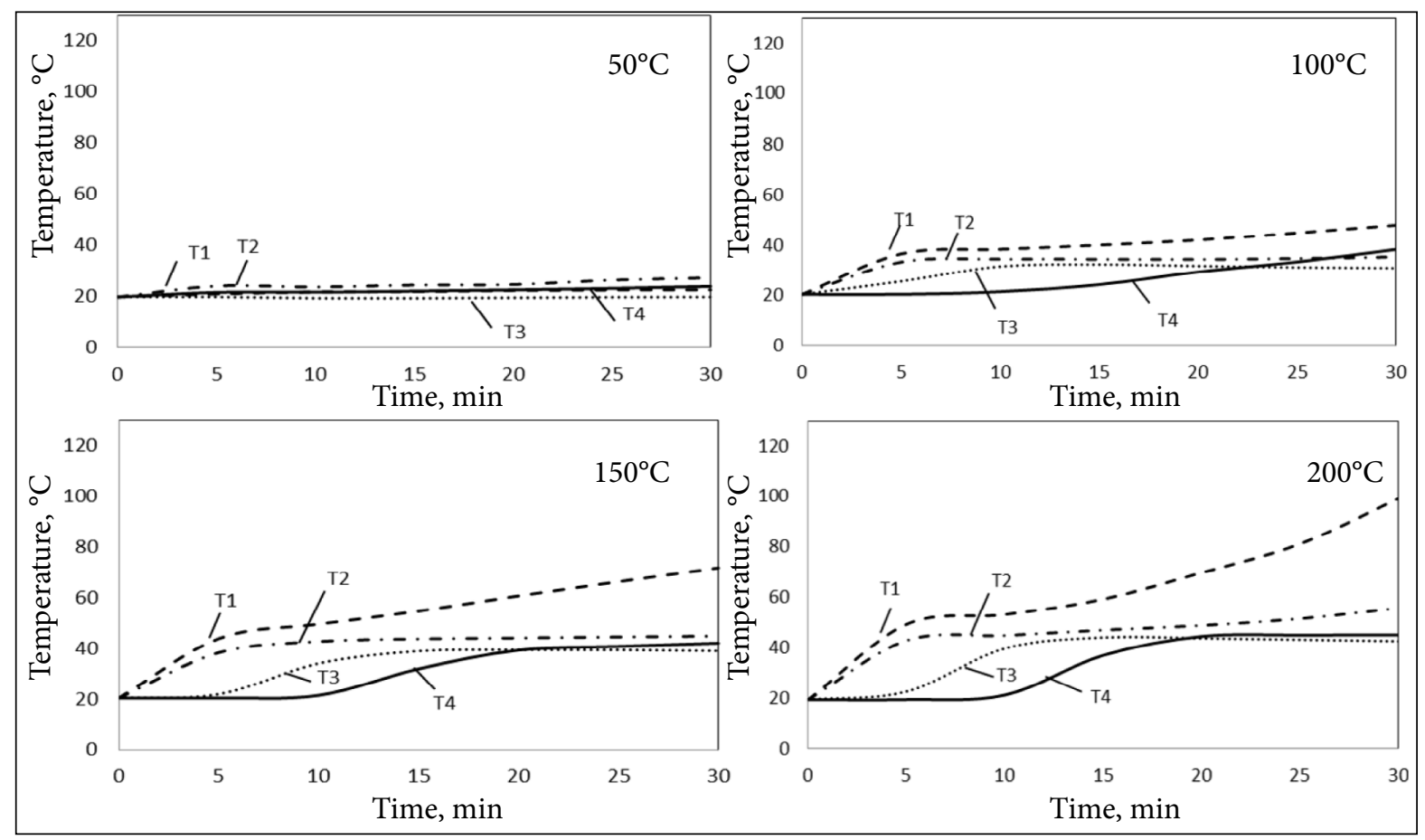

Fig. 7. Heating through of a biofuel bed being dried out with different air temperatures and radiation

change in any layer of the bed or changed very insignificantly; therefore, it can be stated that 30 minutes is insufficient to dry out the lower layer of the bed that is mostly affected by the primary air supply, or the upper one mostly affected by radiation.

When drying biofuel with dry air of $100^{\circ} \mathrm{C}$ temperature and having exposed it to radiation, as the near-wall and lower layers of the bed reach the temperature of $30^{\circ} \mathrm{C}$ at the fifth minute of the experiment, an intense process of condensation and drying begins. The condensation process shifts to an upper layer at approximately 10th minute, and at approximately 23rd minute we observe already the heating of the entire bed and drying of the lower layer of the bed (temperature $\mathrm{T} 1$ increases).

When the sample is exposed to air with the temperature of $150^{\circ} \mathrm{C}$ or $200^{\circ} \mathrm{C}$ and radiation, condensation is insignificant in the lower layer of the bed, which is shown by a rapid increase of reading of the temperature sensor $\mathrm{T} 1$ above $40^{\circ} \mathrm{C}$. When biofuel is exposed to air of $200^{\circ} \mathrm{C}$ temperature and radiation, drying out of the near-wall layer is observed as well. Since the entire heat of radiation is absorbed by the surface of the biofuel sample, no rapid change in the temperature of the upper layer of the bed in this part of the bed was observed for the entire experiment duration.

Estimation of biofuel drying intensity in the biofuel bed by temperature sensors is not a reliable method, as proved by the experiments involving infrared lamps. Although the temperature changes in the bed layers did not show the influence of radiation on biofuel drying; however, determination of the residual moisture in the sample from the moisture content in flue gas shows an evident influence on intensity (Fig. 8). The analysis has shown that the loss of the sample moisture is observed right from the first minute of experiments when drying wood chips at all the temperatures of drying air and exposing the sample to infrared lamp radiation. When blowing air of $50^{\circ} \mathrm{C}$ temperature from below, residual moisture content in wood chips reduces to 0.86 in 30 minutes. If the air temperature is increased to $200^{\circ} \mathrm{C}$, the residual moisture content in the sample after drying for 30 minutes is 0.72 .

\section{Comparison and analysis of results}

The time evolution of biofuel drying was estimated. Residence time has a significant influence when flue gas recirculation products are fed into the furnace drying zone, because a "dead zone" 


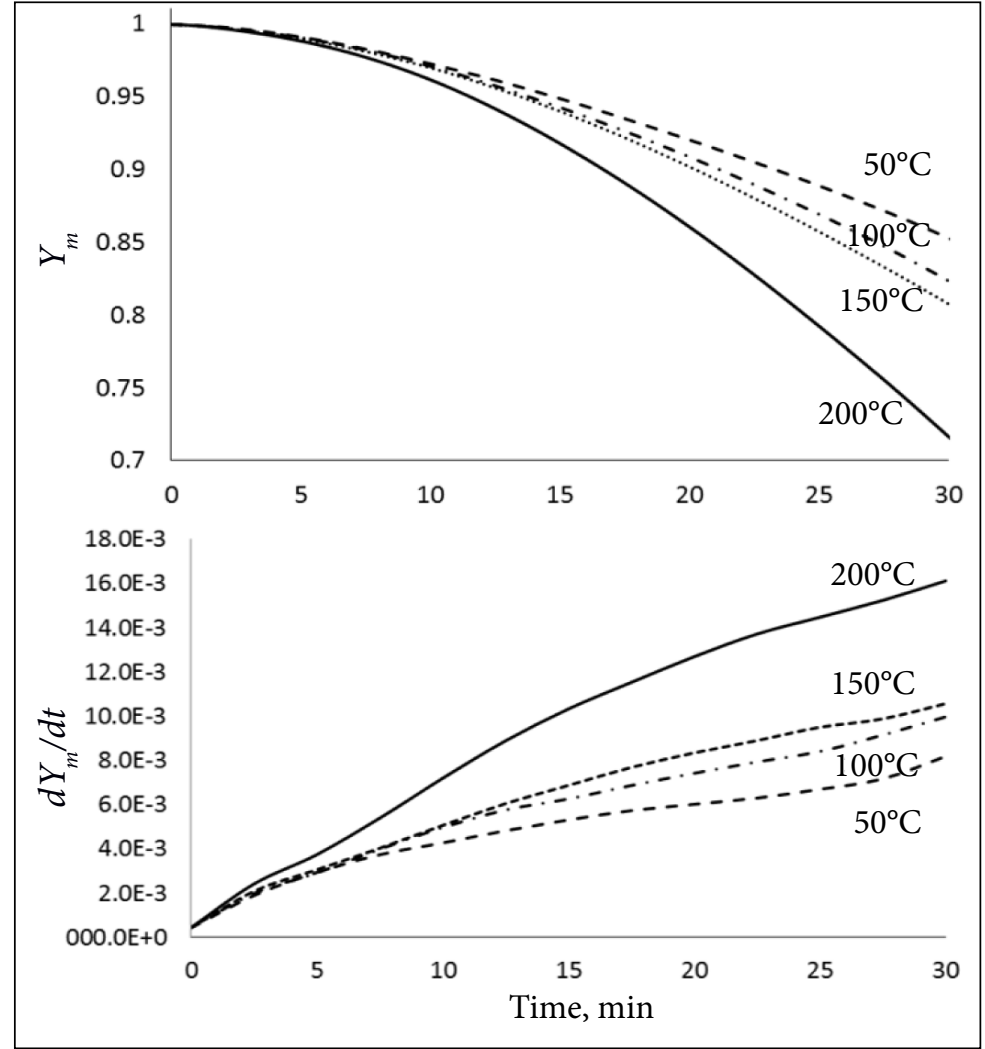

Fig. 8. Residual normalized moisture content $\left(Y_{m}\right)$ and moisture loss rate $\left(d Y_{m} / d t\right)$ : biomass drying with different air temperatures and radiation appears that is important for optimal and safe fuel combustion. The appearance of drying stagnation in a biofuel furnace lasting for approximately 3 minutes is significant when biofuel remains in the drying zone no longer than 10 minutes due to the grate motion velocity. However, if the residence time of biofuel in the drying zone is increased from 10 to $30 \mathrm{~min}$ utes and recirculation products having the temperature of $200^{\circ} \mathrm{C}$ are injected, the stagnation of drying can be ignored. Considering moisture loss when drying the sample at $200^{\circ} \mathrm{C}$ with different drying agents and keeping the drying chamber at $200^{\circ} \mathrm{C}$, the difference of residual moisture content is only $0.2 \%$ (Fig. 9).

By measuring the moisture content of flue gas, it was calculated how much moisture on average was removed when drying fuel with drying agents of different properties. When the drying agent is dry air with temperature of $200^{\circ} \mathrm{C}$, moisture content in a biofuel sample reduces from $57.1 \%$ to $54.7 \%$, and when drying with the airsteam mixture imitating injection of flue gas recirculation products through the grate, the moisture content reduces from $59.5 \%$ to $57.3 \%$. By measuring flue gas humidity, only the average change of moisture content in a biofuel sample can be estimated. Recording changes in temperature helps to understand in what locations humidity is removed more intensely. When injecting dry air heated to $200^{\circ} \mathrm{C}$, the lower layer of the bed dries out intensely and the temperature here reaches $66.4^{\circ} \mathrm{C}$ after 10 minutes, whereas in case of drying with the air-steam mixture, it only reaches $46.8^{\circ} \mathrm{C}$.

Observation of temperature changes in all the layers of the bed implies that drying fuel by the air-steam mixture leads to uniform heating of the bed layers; therefore, humidity is removed uniformly from all the height of the bed. When drying the biofuel sample with the air-steam mixture with the temperature of $200^{\circ} \mathrm{C}$, the heating of the entire bed is observed after approximately 15-20 minutes, where the largest part of the layers is being dried out by saturated steam that transfers heat more intensely than hot air. The heat transfer coefficient of saturated steam is larger than that of air by a factor of approximately 20 [16]. In experiments with preheated air, the major part of thermal energy is spent to dry out the lower layer; therefore, the temperature does not rise as rapidly in the remaining 


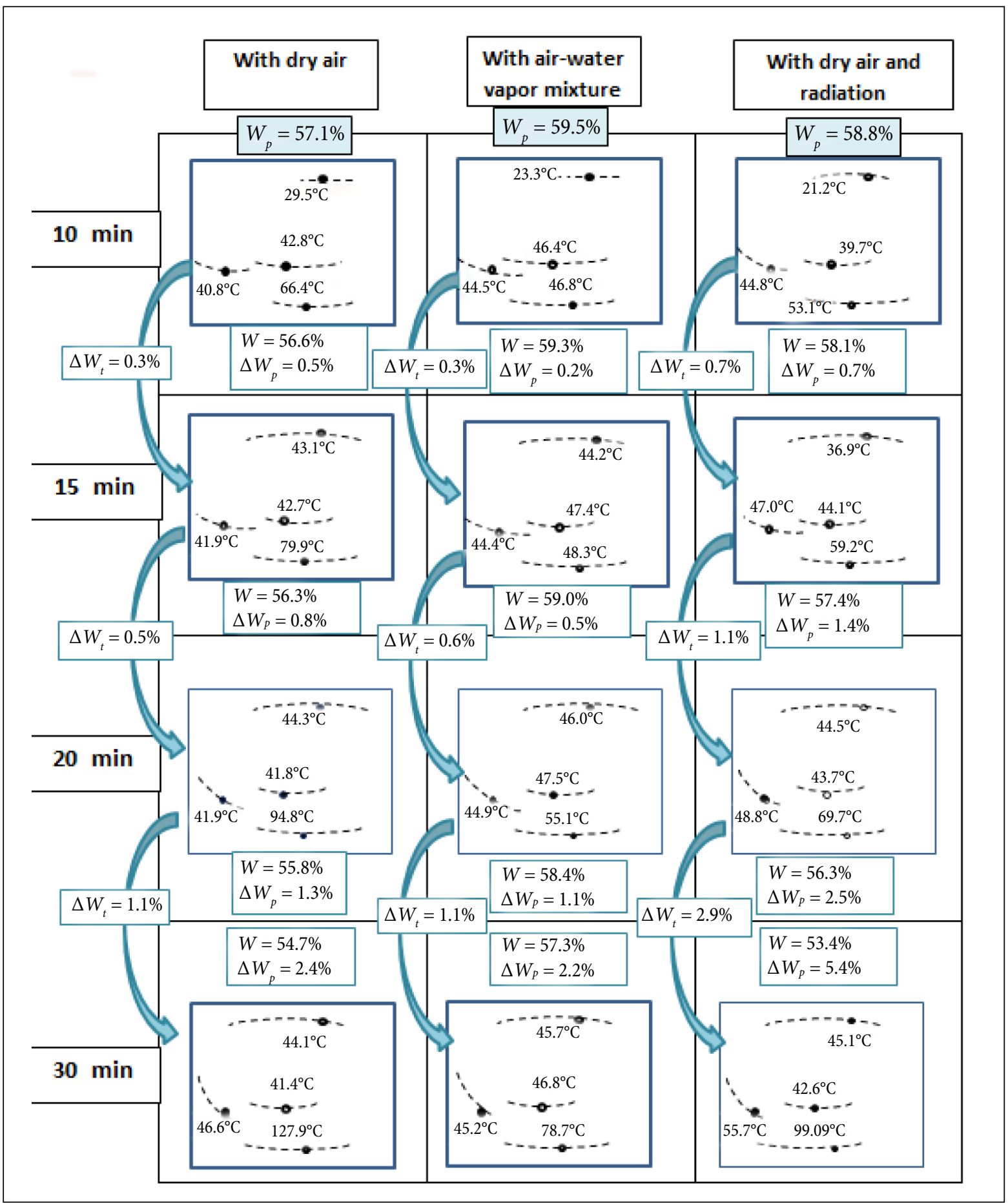

Fig. 9. Drying intensity of wood chips and changes in temperature, where $\Delta w_{p}-$ decrease of moisture content, $\Delta w_{t}-$ moisture content variation, $W_{p}$ - initial moisture content

part of the bed as in case of drying with the airsteam mixture.

Recording temperature changes in various locations of the bed enables to observe heating up of biofuel particles and to model the drying area of the fixed bed. When drying biofuel with hot air of up to $200^{\circ} \mathrm{C}$ and radiating $50 \mathrm{~kW} / \mathrm{m}^{2}$ thermal power to the surface of the bed, it is impossible to fully estimate the drying surface from the temperature changes. The temperature sensor T4 installed in the upper layer of the bed, but on the very top, does not record an abrupt increase 
of the temperature, which implies evidently that radiation from the incandescent surfaces affects only the particles located on the top of the biofuel bed. After drying out for 30 minutes, the temperature in the upper layer of the bed differs by only $1^{\circ} \mathrm{C}$. In this series of experiments, the largest part of the biofuel sample dries out because of the injected air, and only the surface part dries out due to radiation. Even though the temperature changes of surface particles were not observed, we can conclude from intense moisture evaporation to flue gas that the largest part of moisture evaporated from the sample surface due to radiation. When drying the biofuel sample with hot air and infrared lamps, the humidity loss was most intense and the moisture content in the sample was reduced from $58.8 \%$ to $53.4 \%$ in 30 minutes.

\section{CONCLUSIONS}

1. Temperature sensors installed in various locations of the drying chamber have shown that the biofuel bed dries out non-uniformly throughout its height. When drying the biofuel sample with air of different temperatures, the lower and near-wall layers dry out first, and the middle and upper layers dry out only after that. The higher the temperature of the injected air, the higher the moisture loss rate. When drying biofuel with injected air with the temperature of $200^{\circ} \mathrm{C}$, the residual moisture content was reduced from $57.1 \%$ to $54.7 \%$ in 30 minutes.

2. Experiments involving air and water steam mixture have shown that in case of drying wood chips, with all the explored air-steam mixture temperatures, a "dead zone" appears in the beginning of the experiment whose residence time depends on the temperature of the supplied mixture. When drying the biofuel sample with the air-steam mixture of $50^{\circ} \mathrm{C}$ temperature, drying stagnation lasts for even 13 minutes. By extending residence time of fuel in the drying zone and increasing the mixture temperature to $200^{\circ} \mathrm{C}$, the lifetime of the stagnation zone shortens to 3 minutes, and the residual moisture content in biofuel decreases from 0.99 to 0.86 .

3. When using infrared lamps of $50 \mathrm{~kW} / \mathrm{m}^{2}$ thermal power, the overall results have shown that only the biofuel particles located on the sur- face of the bed are being dried out, whereas the bottom layers are not affected. An additional source of thermal energy affects the changes of the drying pattern in the entire biofuel bed, because it enhances heat transfers and slows down condensation in the top layers. The overall loss of moisture of the biofuel bed is higher compared to the case when only convection is involved. It was established that the loss of moisture content was most intense in the sample in this case and reduced from $58.8 \%$ to $53.4 \%$ in 30 minutes.

Received 12 March 2019 Accepted 28 March 2019

\section{References}

1. Dhillon R. S., von Wuehlisch G. Mitigation of global warming through renewable biomass. Biomass and Bioenergy. 2013. Vol. 48. P. 75-89. https://doi.org/10.1016/j.biombioe.2012.11.005

2. Ramanauskas V. Biokuro naudojimas lietuvos šilumos ūkyje - Reali nauda. Iš: EUROPEAN BIOMASS ASSOCIATION (LITBIOMA) 2017.

3. Razmjoo N., Sefidari H., Strand M. Measurements of temperature and gas composition within the burning bed of wet woody residues in a 4 MW moving grate boiler. Fuel Processing Technology. 2016. Vol. 152. P. 438-445. https://doi. org/10.1016/j.fuproc.2016.07.011

4. Quaak P., Knoef H., Stassen H. Energy from Biomass: A Review of Combustion and Gasification Technologies. World Bank, 1999.

5. Bauer R., Gölles M., Brunner T., Dourdoumas N., Obernberger I. Modelling of grate combust ion in a medium scale biomass furnace for control purposes. Biomass and Bioenergy. 2010. Vol. 34. P. 417-427. https://doi.org/10.1016/j.biombioe.2009.12.005

6. Stenström S. Drying of biofuels from the forest - A review. Drying Technology. 2017. Vol. 35. P. 1167-1181. https://doi.org/10.1080/07373937.2 016.1258571

7. Daud W. R. W. Fluidized bed dryers-Recent advances. Advanced Powder Technology. 2008. Vol. 19(5). P. 403-418.

8. Sai P. S. T. Drying of solids in a rotary dryer. Drying Technology. 2013. Vol. 31. P. 213-223. https:// doi.org/10.1080/07373937.2012.711406 
9. Pang S., Mujumdar A. S. Drying of woody biomass for bioenergy: drying technologies and optimization for an integrated bioenergy plant. Drying Technology. 2010. Vol. 28. P. 690-701. https:// doi.org/10.1080/07373931003799236

10. Myllymaa T., Holmberg H., Hillamo H., Laajalehto T., Ahtila P. Wood chip drying in fixed beds: drying kinetics and economics of drying at a municipal combined heat and power plant site. Drying Technology. 2015. Vol. 33. P. 205-215. https:// doi.org/10.1080/07373937.2014.945179

11. Danielsson S., Rasmuson A. The influence of drying medium, temperature, and time on the release of monoterpenes during convective drying of wood chips. Drying Technology. 2002. Vol. 20. P. 1427-1444. https://doi.org/10.1081/DRT120005860

12. Striūgas N., Vorotinskiené L., Paulauskas R., Navakas R., Džiugys A., Narbutas L. Estimating the fuel moisture content to control the reciprocating grate furnace firing wet woody biomass. Energy Conversion and Management. 2017. Vol. 149. P. 937-949. https://doi.org/10.1016/j. enconman.2017.04.014

13. Kortela J., Jämsä-Jounela S. L. Fuel moisture soft-sensor and its validation for the industrial BioPower 5 CHP plant. Applied Energy. 2013. Vol. 105. P. 66-74. https://doi.org/10.1016/j.apenergy.2012.12.049

14. Holmberg H., Ahtila P., Ahtila O. Experimental study on drying of bark in fixed beds. Drying Technology. 2011. Vol. 29(8). P. 953-960.

15. Yin C., Rosendahl L. A., Kær S. K. Grate-firing of biomass for heat and power production. Progress in Energy and Combustion Science. 2008. Vol. 34(6). P. 725-754.

16. The Steam and Condensate Loop. Spirax Sarco, 2014. https://beta.spiraxsarco.com/Learn-aboutsteam
Lina Vorotinskienè

\section{PARAMETRŲ ITTAKA BIOKURO DŽIŪVIMUI DEGINANT KURĄ PAKUROJE SU JUDINAMU ARDYNU}

\section{Santrauka}

Efektyviausias iki šiol naudojamas būdas iš atsinaujinančių energijos šaltinių išgauti energiją yra biokuro deginimas. Šilumos gamybai iš biokuro yra populiariausios ir dažniausiai naudojamos 5-10 MW galios biokuro pakuros su judinamu ardynu. Biokuro deginimas ardinèse pakurose yra gerai išplètota technologija, tačiau norint optimaliai ir saugiai deginti biokurą tokio tipo pakurose jis turi būti aukštos kokybès, pastovaus, neviršijančio 30-45 \% masès, drègnumo. Didejjant biokuro paklausai auga jo kaina, todèl šilumos gamintojai taupo ir perka prastesnès kokybès biokurą, kurio drègnis kartais siekia $60 \%$ ir daugiau. Toks kuras, patekęs ị pakurą ant ardyno, nedega, o džiūsta, sukeldamas degimo proceso nestabilumą ir užgesimo riziką.

Darbo tikslas - išanalizuoti pakuros džiovinimo zonoje vykstančius procesus ir džiūvimą lemiančius veiksnius: pirminị orą, išmetamų dūmų dujų recirkuliacijos produktus ir spinduliavimą nuo ikaitusių vidinių pakuros paviršių. Gautų duomenų analizè atskleis galimus techninius sprendimus siekiant optimaliai deginti kurą tokio tipo pakurose be papildomų investicijų. Biokuro džiovinimo analizė buvo atlikta eksperimentiniame įrenginyje su stacionariu biokuro ịkrovos sluoksniu. Tyrime naudoti medžio skiedrų bandiniai, kurie buvo džiovinami esant keturioms skirtingoms džiovinimo agento temperatūroms.

Tyrimų rezultatai parodè, kad didžiausią ịtaką biokuro bandinių džiūvimo greičiui turi spinduliavimas nuo vidinių pakuros paviršių. Palyginti su pradine mase, per $30 \mathrm{~min}$. bandinio drègmès kiekis sumažèjo 5,4 \%.

Raktažodžiai: biokuras, pirminis oras, pakura, spinduliavimas 